九州大学学術情報リポジトリ

Kyushu University Institutional Repository

\title{
Cretaceous-Tertiary Unconformity in the Western Part of Amakusa-Shimoshima
}

Miki Takashi

Faculty of Science, Kyushu University

https://doi.org/10.5109/1544094

出版情報：九州大學理學部紀要：Series D, Geology. 21 (2)，pp.217-237，1972-12-25. Faculty of Science, Kyushu University バージョン：

権利関係 : 
Mem. Fac. Sci., Kyushu Univ., Ser. D, Geol., Vol. XXI, No. 2, pp. 217-237, text-figs. 1-9, tables 1-2, plates 34-35, December 25, 1972

\title{
Cretaceous-Tertiary Unconformity in the Western Part of Amakusa-Shimoshima
}

\author{
By \\ Takashi MIKI
}

\begin{abstract}
In Amakusa-Shimoshima the Paleogene and the Cretaceous are widely distributed. An unconformity beneath the Paleogene Fukuregi Formation is quite well traced throughout the western part of this island. The formations below and above this unconformity show considerable dissimilarities in fossil contents, sedimentological characters, and geological structure.
\end{abstract}

\section{Introduction and Acknowledgements}

The problem of the Cretaceous-Tertiary boundary is important and interesting, and has been discussed by many geologists in the world. The problem contains two subjects, one is the decision of the biostratigraphic boundary between the two systems and the other is to make clear the actual relationship of them in each district, where the two systems are in contact.

In the Amakusa islands, Kumamoto Prefecture, the Cretaceous and the Tertiary System are so widely distributed that the area is one of the best fields to study the relationship between the two systems. The Amakusa islands consist of two major islands, Kamishima in the east and Shimoshima in the west, and several small islets. In Kamishima, the Cretaceous and the Tertiary are easily discriminated from each other; the latter overlies the former with a distinct unconformity. In Shimoshima, on the other hand, the relationship between the two systems has remained unsolved, although there were various opinions.

For several years, the writer has investigated the Cretaceous and the Tertiary in the western part of Shimoshima to contribute to the boundary problem. In this paper, the geology of the surveyed area is described at first, and then, the stratigraphic relationship between them is discussed from structural, stratigraphical and sedimentological points of view, and some general problems are also described.

The writer expresses his sincere gratitude to Professor Emeritus Hisamichi MATSUSHITA for supervision and encouragement. He would like to give his hearty thanks to Professor Ryohei TAKAHASHI for helpful suggestions and discussions. It is a pleasure to acknowledge the instructive help of Professor Tatsuro Matsuмото for this study. Thanks are due to Professor Ryuzo Toriyama, Professor Hideo Urata, Professor Jyonosuke OHARA, Dr. Itaru HaYAmi and Dr. Suzuomi 


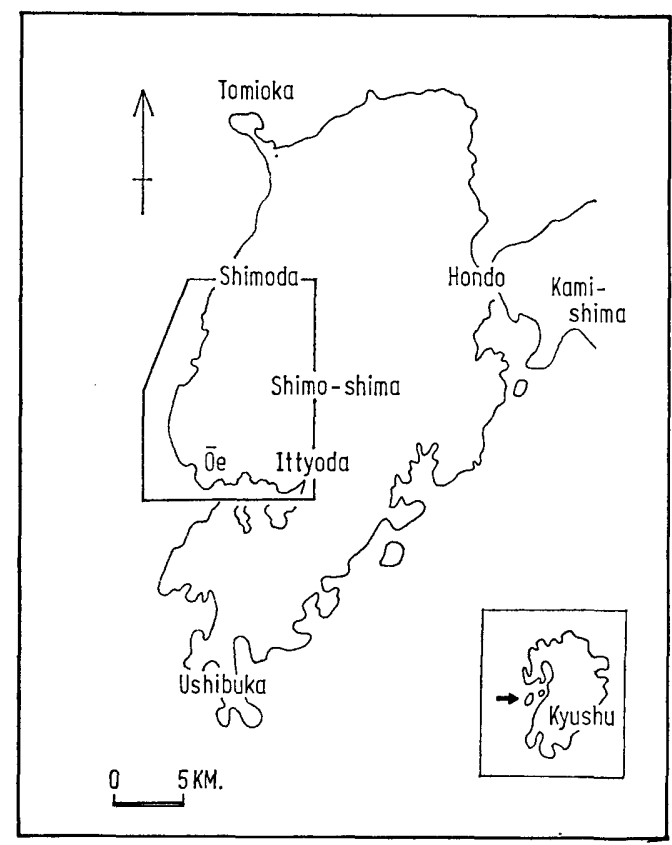

Fig. 1. Index map of the surveyed area.

Tomita of Kyushu University. The writer is also grateful to Dr. Yasuaki TAKaI of the Geological Survey of Japan for providing his unpublished data and for his kind discussions.

A part of this study was supported by the Scientific Research Fund from the Ministry of Education and the Takachiho Fellowship of Kyushu University.

\section{Geology}

The western part of Shimoshima is geologically composed of metamorphic rocks, the Cretaceous, Tertiary and Quaternary deposits, with a small amount of igneous rocks. The stratigraphy of the surveyed area is summarized in Table 1.

The metamorphic rocks are distributed in the area extending from oe northward to Takahama, Amakusa Town. They are in contact with the Cretaceous by faults. They exhibit remarkable micro- and mega-folding structures, and really, both the strike and the dip change markedly from place to place. The metamorphic rocks are composed chiefly of the so-called green schists, muscovite schists and quartz schists, and locally contain cataclasite. The so-called green schists can be further divided into actinolite schist, chlorite schist, etc. As a whole, the rocks are predominated with muscovite schist. Besides them, a small body of clino-pyroxene peridotite crops out along the river of okōchi, east of Takahama.

The Diluvial and Alluvial deposits are limited in distribution in the mapped area. The former is classified into talus deposits in the mountain land, terrace gravel sediments of small scale along the rivers, and gravel beds in the Tororo district. They are composed of gravels, sands and clays. The Alluvial deposits 
Table 1. Stratigraphical table.

\begin{tabular}{|c|c|c|}
\hline Age & \multicolumn{2}{|c|}{ Stratigraphy } \\
\hline \multirow{2}{*}{ 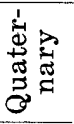 } & \multicolumn{2}{|c|}{ Alluvial Deposits } \\
\hline & \multicolumn{2}{|c|}{ Diluvial Deposits } \\
\hline \multirow{6}{*}{ 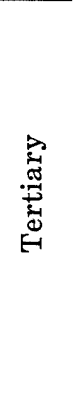 } & \multicolumn{2}{|c|}{$\begin{array}{l}\text { Lithoidite, Porphyrite, } \\
\text { Dolerite, Andesite }\end{array}$} \\
\hline & \multicolumn{2}{|c|}{ Sakasegawa Formation } \\
\hline & Ittyoda & F. \\
\hline & Toishi & F. \\
\hline & Shikiyama & F. \\
\hline & Fukuregi & F. \\
\hline \multirow{8}{*}{ 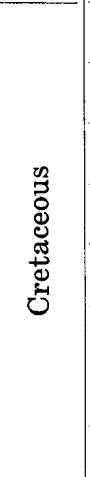 } & $\mathrm{H}$ & F. \\
\hline & $\mathrm{G}$ & F. \\
\hline & $\mathrm{F}$ & F. \\
\hline & $\mathrm{E}$ & F. \\
\hline & $\mathrm{D}$ & F. \\
\hline & $\mathrm{C}$ & F. \\
\hline & $\mathrm{B}$ & F. \\
\hline & A & F. \\
\hline 离: & Metamorp & hic Rocks \\
\hline
\end{tabular}

are distributed near the coast lines of the western and the southern margin and also along the rivers.

Some kinds of igneous rocks are distributed in the mapped area as dykes or intrusive sheets. Their ages cannot be exactly determined but it is presumed that most of them are post-Paleogene in age. The igneous rocks are classified into three groups, olivine dolerite, andesitic rocks and lithoiditic rocks.

\section{A. Cretaceous formations}

A greater part of the mapped area is composed of the Cretaceous formations. There has been a considerable divergence of opinions as to the division of the Cretaceous formations and their geological age. Such being the case, the Cretaceous deposits of the area are divided into eight formations chiefly from the lithostratigraphic point of view from $\mathrm{B}$ to $\mathrm{H}$ in ascending order and an isolated unit $\mathrm{A}$, but these divisions are tentative. Detailed discussions on the geological age of these formations are given later. All the formations, except A, are conformable with each other, and come in contact with the metamorphic rocks by faults. They are partly covered with the Quaternary deposits, and are thermally affected by the Tertiary igneous rocks. 

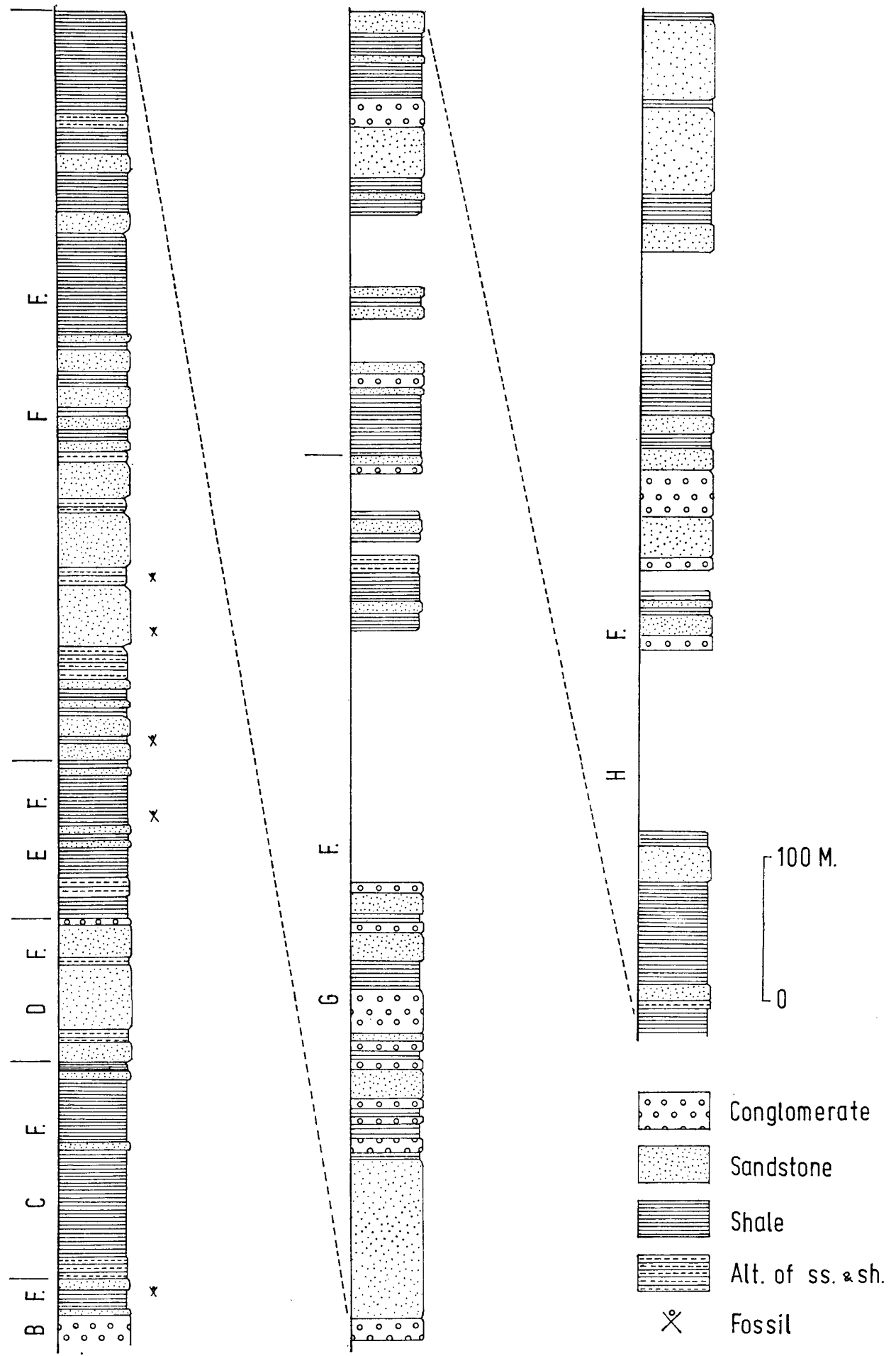

Fig. 2. Generalized section of the Cretaceous formations. 


\section{a. A-Formation}

Type Locality: A mountain path of Funatsu, Amakusa Town

It is distributed in a very narrow area as a klippe on the crystalline schists. It consists of medium grained sandstones with a thickness of more than $20 \mathrm{~m}$. Further detailed description can not be given because of intense decomposition. Although geological situation of the A-Formation is not known owing to its isolated occurrence and indistinct litho-facies, it is tentatively presumed to be the lowest part of the Cretaceous System of the area.

\section{b. B-Formation}

Type Locality: The Yokohama Bay, oe, Amakusa Town

This is distributed in a limited narrow area around 0 e. It consists of conglomerates, sandstones and shales, attaining at least $50 \mathrm{~m}$ in thickness. It has coarser grained sediments than the C-Formation. Shales are black in color and sandstones are feldspathic arenite with a little rock fragment. A fossil bed containing a number of molluses such as Glycymeris is found in the lower part of this formation.

Judging from the gradual change in the strike and dip of the strata as shown in Fig. 9, an anticlinal structure is evidently concluded, with an axis passing through the central part of the bay from north to south. The anticline is named the 0 e Anticline in this paper. In the western wing of the anticline, the strata are in general strongly disturbed and a number of minor foldings are met with.

The formation may correspond roughly to the $\mathrm{H}_{1}$-Formation of HATAE (1959).

\section{c. C-Formation}

Type Locality: Tōzaki-Tōge, Amakusa Town

The formation is finely exposed at the southwest of oe in addition to the type locality. In the northern part of the mapped area, it is distributed in the Ozaki-Shimoda district. Its thickness is $135 \mathrm{~m}$ on the average.

If consists mostly of black or grayish black shales and siltstones and partly contains well bedded alternations of shale and siltstone, but in the northern part, the Takahama-Tororo area, a considerable amount of well bedded, mostly of fine to medium grained sandstones is contained.

The strike and the dip of the strata change from place to place near the type locality. In the Takahama-Tororo area, the strata form an anticlinal structure called the Ozaki Anticline by Matsushita et al. (1959).

An occurrence of Inoceramus balticus toyajoanus NAGAo et MATSUMOTo in this formation is reported by HATAE (1960).

This formation may roughly correspond to the $\mathrm{H}_{2^{-}}$and $\mathrm{H}_{3}$-Formation of HATAE (1959) and to the lower part of the $\alpha$-Formation of Matsushita et al. (1959).

\section{d. D-Formation}

Type Locality: Töge-the east of Ikusagaura, Amakusa Town

The D-Formation is distributed in the southern part of the mapped area, 
and further in the Kikaigaura-Sarayama-Uchiyama area of the northern part.

It is composed of sandstones and a lesser amount of conglomerates. Sandstones are hard and dark brown, usually medium to coarse, and become conglomeratic at places. They belong to the lithic arenite type in which rock fragments are abundant and matrices are poor. In general, the formation are coarser in the Takahama-Tororo area than in the Sakitsu-Takahama area of the southern part, and predominant in conglomerates. Shales are black or grayish black, and often become tuffaceous in the northern part.

The strata are remarkably sheared and disturbed, being often cut by faults.

The formation roughly corresponds to the $\mathrm{H}_{3}$-Formation of HATAE (1959) and to the middle part of the $\alpha$-Formation of Matsushita et al. (1959).

\section{e. E-Formation}

Type Locality: Ikusagaura, Amakusa Town

The formation consists chiefly of fine grained sediments and develops near and around Ikusagaura and further northward in Shimodaminami, Matsunohira and Kayanoki. The thickness attains to $110 \mathrm{~m}$ at the type locality.

The formation is predominant in shales with intercalations of a fair amount of sandstone and alternations of sandstone and shale. Conglomerates are also partly contained. Shales are black, and sometimes grayish or purplish in the northern part. Sandstones are grayish blue, and hard, and they belong mostly to lithic arenite. At the west of Ikusagaura, a fossiliferous part is found in the alternated sandstone and shale.

The formation corresponds roughly to the $\mathrm{H}_{4}$-Formation of HATAE (1959) and to the upper part of the $\alpha$-Formation of MATSUshita et al. (1959).

\section{f. F-Formation}

Type Locality: Ikusagaura-the east of Kodakahama

The formation is distributed in the Shimodaminami-Kokuryū-Komatsu area besides the type locality. It is $540 \mathrm{~m}$ in thickness.

In the main part coarse grained sediments containing thin shale beds predominate, but the upper part becomes rich in black shales. Sandstones are bluish gray or dark bluish green, coarse and hard, often become conglomeratic possessing shale patches. The sandstones are hardly discriminated from the so-called "Fukami Sandstone" of Nagao (1926). Most of the sandstones belong to feldspathic arenite. Mineral grains are angular or sub-angular and poorly sorted.

Intraformational foldings and slidings along the bedding planes are frequently observed. The formation is considered to be formed under an unstable environment judging from the slumping structures observed at some places. Molluscan fossils such as Apiotrigonia postonodosa NAKANo are contained in the lower part of the formation.

There is no remarkable change in litho-facies between the F-Formation and the superjacent and subjacent formations, but a gradual and minor change is found throughout the formation.

This formation correspond to the lower part of the $\mathrm{H}_{5}$-Formation of HATAE (1959) and to the $\beta$-Formation of MATSUSHITA et al. (1959). 


\section{g. G-Formation}

Type Locality: the east of Kodakahama-Sakitsu, Kawaura Town

It is distributed around Sakitsu in the southern part and in the TakahamaSarayama-Kokuryü-Komatsu area of the north. The thickness is measured at $645 \mathrm{~m}$ at the type locality, and about $500 \mathrm{~m}$ in the northern area.

The lower part consists mainly of conglomerates accompanied with sandstones and shales, and in the upper part, an amount of shales gradually increases. Conglomerates contain granules and pebbles. Sandstones are very coarse to medium, bluish green to bluish gray, and change to yellow by weathering. Most of the sandstones belong to feldspathic arenite in the southern part but change to lithic arenite in the northern part due to the increasing of volcanic fragments. Sandstones are composed of quartz, feldspar, biotite, muscovite, chlorite, zircon, calcite, etc., many of which are sub-angular and moderately sorted. Shales are black and tuffaceous ones are sometimes gray and purple. At an outcrop on the coast road of the southern part, a layer of fine grained and grayish white acidic tuff of $120 \mathrm{~cm}$ in thickness is found, which does not continue laterally for a great distance.

Since intraformational disturbances are occasionally recognized, the formation might be accumulated under an unstable environment. At many outcrops, particularly those near the coast, various kinds of disturbed structures are observed. It is presumed that these abnormal sedimentary structures are resulted from the preceding disturbance occurred prior to the principal structural movement, which was taken place after the deposition of the H-Formation.

G-Formation corresponds to the upper part of the $\mathrm{H}_{5}$-Formation and the lower part of the $\mathrm{H}_{6}$-Formation of HATAE (1959) and to the $\gamma$-Formation and the $\delta$-Formation of Matsushita et al. (1959).

\section{h. H-Formation}

Type Locality: Shitanoharu-Hirowatase, Amakusa Town

The formation, which is $415 \mathrm{~m}$ in thickness, consists of conglomerates, sandstones and shales, and shales are contained more abundantly than in the underlying G-Formation. Pebbles of conglomerates are usually granule to cobble in size, and mostly those of chert. Limestone pebbles reaching occasionally to $20 \mathrm{~cm}$ in diameter are sometimes included. Sandstones, which used to be called the "Fukami Sandstone", are bluish green and hard, containing abundant rock fragments, particularly of volcanics. Grains of sandstones are sub-angular and moderately sorted. Shales are generally black. The strata are remarkably sheared. Calcite veins are intruded into the strata.

The H-Formation corresponds roughly to the upper part of the $\mathrm{H}_{6}$-Formation and the lower-middle part of the Akashimisaki Formation of HATAE (1959) and to the Fukami Formation of Matsushita et al. (1959).

\section{B. Paleogene formations}

The division and the correlation of the Paleogene formations, excepting the lowest unit, are chiefly followed the scheme given by MATsushita (1949) who divided the Paleogene of Shimoshima into three groups, the Akasaki, the Kami- 


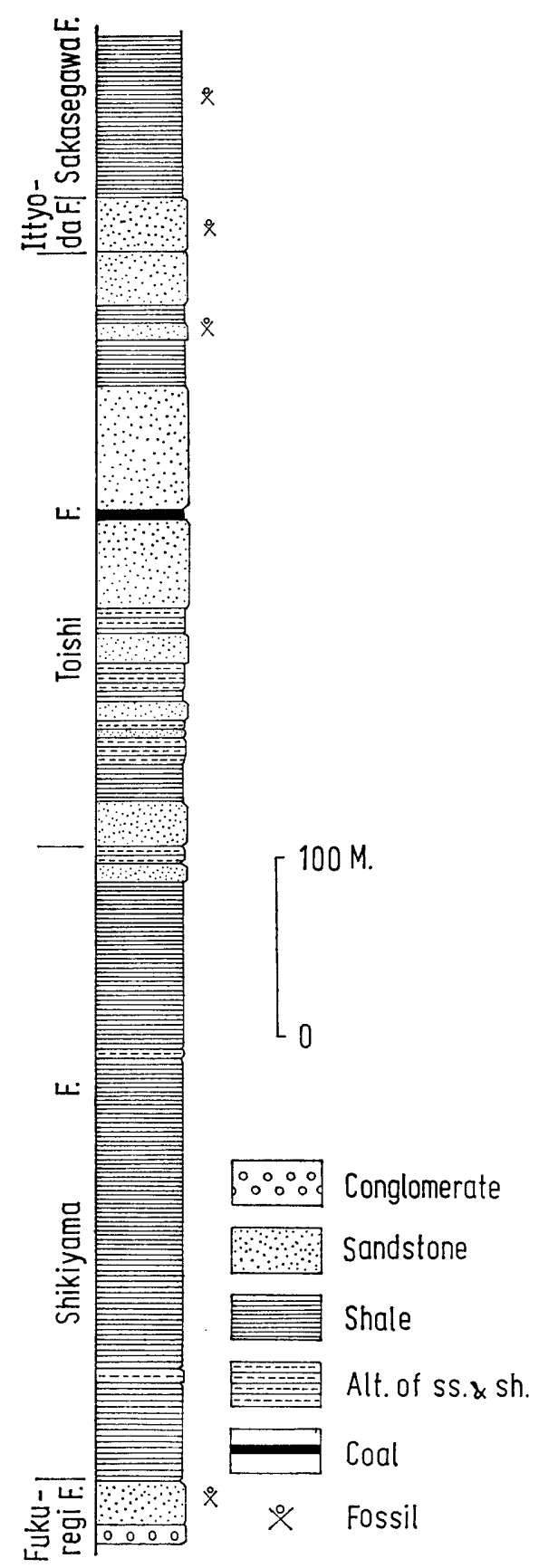

Fig. 3. Generalized section of the Tertiary formations.

shima and the Sakasegawa Group in ascending order. The H-Formation includes the strata, which were once included in the Paleogene, is regarded in the present paper as the uppermost part of the Upper Cretaceous from the evidence described later, and the Fukuregi Formation, therefore, as the basal part of the Paleogene. 


\section{Kamishima Group}

The Kamishima Group consists of the Fukuregi, Shikiyama and Toishi Formations in ascending order. The Fukuregi and the Shikiyama Formation correspond respectively to the Shiratake and the Kyōragi Formation in Kamishima.

\section{a. Fukuregi Formation}

In Shimoshima, the formation crops out typically in the Fukuregi area, Amakusa Town, and is distributed from the north of Tororo to Nakayama, Kawaura Town.

It consists mainly of medium to coarse grained sandstones and granule conglomerates. They are white in color. This color is useful to discriminate this formation from the underlying strata. In the uppermost part, fossiliferous bluish sandstone is found. The sandstones of this formation are classified into feldspathic arenite, feldspathic wacke, and lithic wacke containing a fair amount of rock fragments of chert and sandstone.

The Fukuregi Formation has a thickness of $35 \mathrm{~m}$ at the type locality, and the thickness reduces to $27 \mathrm{~m}$ at Jüsanno, Kawaura Town. By its characteristic lithologic characters, the formation is traced southward to Nakayama, where it is cut off by a fault.

The Fukuregi Formation lies unconformably on the H-Formation in Hotokenohira, Jüsanno and the east of okōchi, and directly on the G-Formation in the south of Fukuregi.

The formation yields fossils such as Colpospira tashiroi KoTAKa, Discocyclina sp., Tellina sp., Crassostrea sp., etc.

\section{b. Shikiyama Formation}

The Shikiyama Formation was named by Matsushita (1949) for the stratigraphical unit in Shimoshima which is equivalent to the Kyōragi Formation of NAGAO (1926). The Shikiyama Formation in this paper is the same as that of Matsushita (1949).

The formation is widely distributed in the Shiki area, Reihoku Town, in the northern part of Shimoshima island and in Kanayama, Kojima, Fukuregi areas and their environs in the surveyed area.

The formation is composed chiefly of shales with occasional intercalation of thin sandstone; especially in the transitional part to the overlying Toishi Formation, a great number of sandstone beds is intercalated. Shales are black, consisting of quartz, feldspar, calcite and clay minerals. They keep the same lithological characters through the formation. Blade-like cleavages are developed in the shale. Most of the sandstones intercalated in the shales are medium grained and the arenite type, being rich in quartz. They are not much different from those of the Toishi Formation.

Generally, the strata have strikes of NS to NE-SW and dips of $25^{\circ}-40^{\circ}$ to the east, but they are often disturbed by faults and minor foldings.

\section{c. Toishi Formation}

The Toishi Formation is conformable either with the underlying Shikiyama 
Formation and the overlying Ittyoda Formation. The formation occurs from the west of Ittyoda to the north of Kojima through Hachikubo, and then, turns to Kama and Ittyoda, forming a semi-basin structure in the environs of Mizukoshi. The thickness is about $320 \mathrm{~m}$ on the average.

The Toishi Formation is composed chiefly of sandstones, partly with intercalations of shale, coaly shale and coal. Sandstones are, as a whole, medium to fine grained, but they occasionally become coarse and conglomeratic in the Tororo area. They are bluish gray on fresh exposures, but become brown when weathered. Besides a large amount of quartz, muscovite fragments are often contained along the bedding planes of the sandstones. Carbonaceous matters are also found. Shales are black or grayish black and show an onion structure at times. The formation is the only coal-bearing formation in Shimoshima island, and many collieries, such as Shiki, Takenosako, Imatomi, etc. in the western part of the island had been worked. The main coal seams are found at three horizons, which are called San-jaku-, Ni-shyaku- and Hassun in descending order.

The formation occasionally shows intraformational disturbances presumably originated in submarine sliding during sedimentation.

\section{Sakasegawa Group}

The Sakasegawa Group is divided into the Ittyoda and the Sakasegawa Formation, and corresponds to the Sakasegawa Group of NAGAo (1926), MATsushitA (1949) and HATAE (1960). The upper limit of the group is unknown in the surveyed area.

\section{a. Ittyoda Formation}

The formation consists mainly of medium grained sandstones except for the upper part where the sandstones become very coarse and granule conglomeratic. It is $25 \mathrm{~m}$ thick on the average.

The sandstones are really characteristic and useful as a good key bed because of their greenish color due to glauconite and of the abundance of marine fossils such as Lima amakusaensis YokoYama, Lima nishiyamai (YokoYama), Crassatellites sp., Venericardia sp., etc.

\section{b. Sakasegawa Formation}

The formation is the observable uppermost unit of the Tertiary sediments in this area and distributed in the west of Ittyoda surrounding the axis of the Ittyoda Syncline. It lies on the Ittyoda Formation conformably and is in several places covered with the Quaternary deposits.

The formation consists mostly of black or grayish black shales through the formation, and thin sandstone beds are partly sandwiched. Shale beds are not so much disturbed like those of the Shikiyama Formation, being normal in order. They tend to be weathered into onion-shapes. Sandstones are mostly fine grained and often contain glauconite grains. 


\section{Unconformity between the Cretaceous and the Paleogene}

\section{A. Historical review}

The Cretaceous and Tertiary sequence in the Shimoshima island has been studied by several geologists, since it was studied at first systematically by NAGAO (1926). As shown in Table 2, there has been a considerable confusion with respect to the stratigraphic division and the age determination of the subdivided unit.

NAgao (1926) and Matsushita (1949) described that the Fukami Formation, which corresponds roughly to the H-Formation in this paper, was the lowest part of the Paleogene sequence in this area but a remarkable clinounconformity was not found between the Fukami Formation and the underlying strata. MATSUshita et al. (1959) reported that an unconformity was recognized not only beneath the Fukami Formation but also below the Fukuregi Formation.

Table 2. Subdivisions of the Cretaceous and the Tertiary formations by some workers.

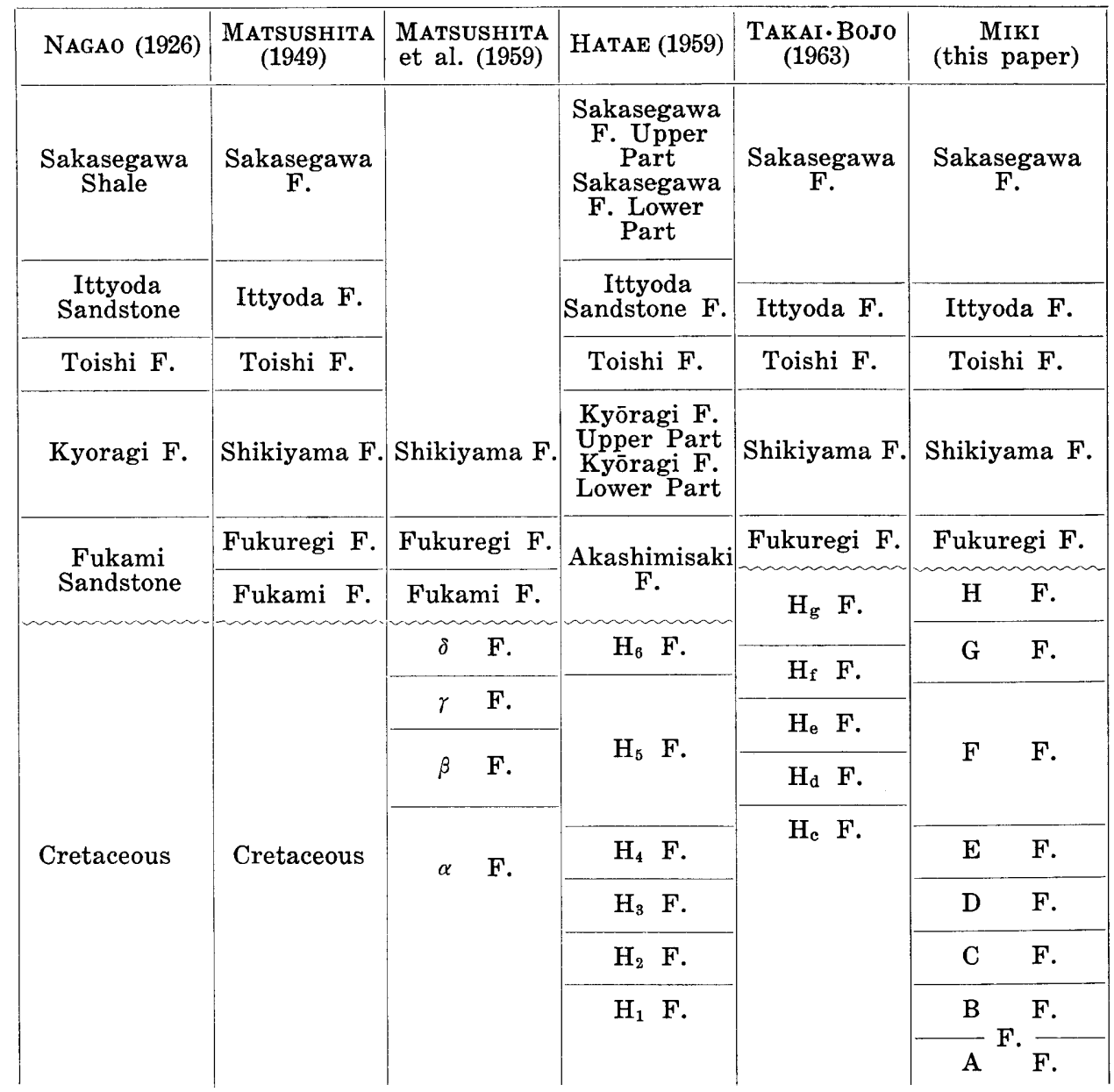


HATAE (1959) put a new interpretation that the boundary between the Cretaceous and the Paleogene was found beneath the Akashimisaki Formation, the lower and middle parts of which are included in the H-Formation as shown in Table 2.

Although various opinions have been proposed as to the relation of the Cretaceous and the Tertiary formations in Amakusa-Shimoshima, the problem has remained unsolved. In this paper the unconformity between the two systems is definitely concluded, but owing to the deficiency of paleontological evidence, the magnitude of the time gap represented by the unconformity is not precisely determined.

\section{B. Litho-facies and unconformity}

Five formations from $B$ to $F$ are a conformable series of sediments. On the grounds of contained fossils, such as Apiotrigonia postonodosa NAKaNo from the F-Formation, Inoceramus balticus toyajoanus NAGAO et MATSUMoTo from the C-Formation, etc., they are evidently of Upper Cretaceous (Senonian) age. The F-Formation is rich in sandstone and contains shale and conglomerate partly. In the G-Formation, the sediments become coarser, with predominant conglomerates. The H-Formation is also composed of coarse grained sediments such as conglomerate and sandstone although shales are often intercalated between them.

As mentioned already, it may say from the viewpoint of litho-facies that the formations from $\mathrm{F}$ to $\mathrm{H}$ are a series of sediments accumulated in almost the same sedimentological condition and that the G- and the H-Formation are also of Upper Cretaceous in age.

At several localities, on the other hand, an unconformity can be clearly ascertained between the H-Formation and the Fukuregi Formation. The latter is referred to Eocene on the evidence of fossils such as Colpospira tashiroi KoTAKa, Discocyclina sp., etc. At Hotokenohira, the Tertiary sediments composed of conglomerates and sandstones containing fossil foraminifers overlie unconformably the shales which are regarded as a part of the H-Formation. At Jüsanno, sandstones of the Fukuregi Formation cover the shales of the H-Formation irregularly. At the east of okōchi, white coarse sandstones of the Fukuregi Formation cover clino-unconformably the black shales and the bluish coarse sandstones of the H-Formation.

An unconformity was reported by HATAE (1959) beneath the Akashimisaki Formation, but, according to the writer's observation it is found beneath the Fukuregi Formation, namely between the upper part and the middle part of the Akashimisaki Formation. As far as observed in the field, the lower part of the so-called Akashimisaki Formation and the underlying strata of unmistakable Cretaceous are conformable with each other.

\section{Note on the time-gap represented by the unconformity}

Formerly, the Akasaki Formation and the Fukami Formation have been regarded as the deposits of the same age but of different litho-facies. However, the writer considers that they are different in ages, namely the so-called Fukami Formation (MATSUSHITA et al., 1959) is referred to the Cretaceous, corresponding approximately to the H-Formation in the present paper. Consequently, the 
lower to middle part of the Akashimisaki Formation (HATAE, 1959), which roughly corresponds to the so-called Fukami Formation, is Cretaceous, and the upper one is Paleogene in age. Inoceramus balticus toyajoanus NAGAO et MATSUмото which is found in the C-Formation in Shimoshima is contained also in the upper part of the Middle Formation in Kamishima. Consequently, these two horizons can be correlated with each other. Then, comparing the thickness of the sediments above these fossil-bearing strata in the two areas, it may be possible to presume that the strata younger than those in Kamishima are developed in Shimoshima. On the other hand, the Akasaki Formation, the basal red beds of the Tertiary sequence in Kamishima, is nowhere exposed in Shimoshima. The Shiratake Formation which conformably overlies the Akasaki Formation contains the same fossils as those of the Fukuregi Formation, and they resemble each other in lithologic characters. On the basis of these facts, the strata equivalent to the upper part of the Cretaceous in Shimoshima and those to the Akasaki Formation are probably lacking in Kamishima and in Shimoshima respectively. Although the available fossils are not sufficient, there is no positive evidence to indicate the Maestrichtian and the Paleocene stage. The existence of a part of the Maestrichtian is possibly considered, because a thick series of conformable strata come above the probably Campanian Inoceramus balticus-bearing bed and because they resemble in litho-facies the Campanian-Maestrichtian Izumi Group of Shikoku and central Honshu. The Paleogene formations above the unconformity, on the other hand, have some useful fossils. Nummulites amakusensissubamakusensis YABE et HANZAWA, which is found in the Fukuregi Formation in the eastern part of Shimoshima is Ypresian or Lower Lutetian in age (YABE and HANZAWA, 1925). Foraminiferal fossils occurred also in the formations from Shikiyama to Sakasegawa and they show Eocene age, and the Sakasegawa Formation, the uppermost of the Paleogene sequence in Amakusa, has Globigerina eocenica TERQUEN, G. ouachitaensis BANDY, etc. and its age ranges from Upper Eocene to Lower Oligocene (Asano and MuRATA, 1957). As already described, the time-gap represented by the unconformity is regarded to be considerably large, although it may change to some extent from place to place (see also TAKAI and Matsumoto, 1961).

\section{Structural differences}

In this section, the observed geological structure are described and then the tectonic differences between the formations above and below the unconformity are discussed.

\section{Faults}

\section{a. Faults elongated in NNE-SSW direction}

Many faults of a large scale running NNE-SSW and NNW-SSE in direction are considered to have been formed at the same time. Thrust faults and high angle reverse faults are also counted.

(1) Tōge Fault It is observed at Tōge, Amakusa Town, with a strike of NNESSW. It runs through the Cretaceous terrain and is cut off by the סe-Sakitsu 


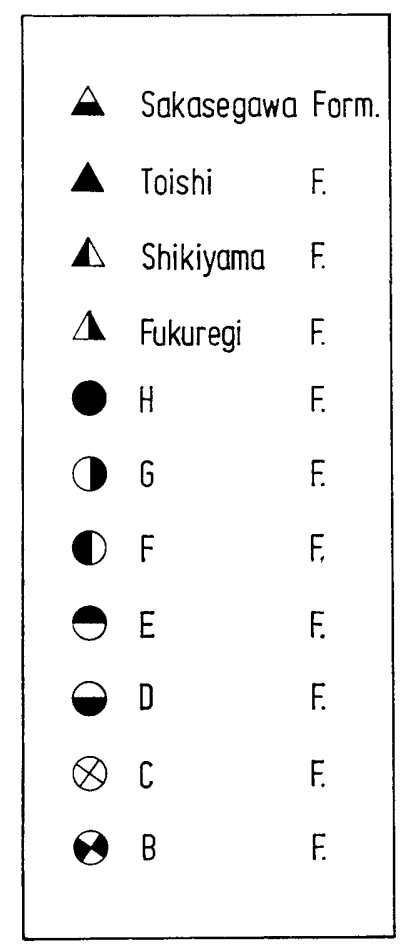

Fig. 4. Indexes for diagrams.

Fault at its northern limit. The fault might be a thrust fault caused by the compressional stress of $\mathrm{E}-\mathrm{W}$ direction.

(2) Mukae-ōkōchi Fault It runs in NNW-SSE direction from Mukae, Kawaura Town, to Takahama through Imatomi. At an outcrop in Mukae, an alternation of sandstone and shale on the right wall of the fault is dragged, and a shaly part on the left wall is folded in minor scale.

(3) Kojima Fault It runs from the west of Kojima to Nakayama in the direction of NNW-SSE. According to the writer's observation, at the west of Kojima, this fault seems to be a reverse fault formed by the compressional stress of E-W direction. The H- and the Shikiyama Formation are in directly contact with each other by this fault.

(4) Other faults A fault runs parallel to the shore line in the KikaigauraShimoda district, and continues to the north of Tororo, being cut by the faults of NW-SE direction at some places. A dike of lithoidite is intruded along the fault line in the Shimoda-Kayanoki district. Judging from the geological map, another fault may run in the Suwa-Ozaki district. Several small scale faults of NE-SW direction are found at places, and many of them are intercepted by the faults of NW-SE direction described below.

\section{b. Faults having NW-SE direction}

They intercept the faults described in the preceding section. There are many faults of this type, and they make the structure of this area further complicated. 
(1) $\bar{o} e$-Sakitsu Fault It is a thrust fault having inclination to the northeast and runs from oe to the west of Kojima. It is exposed at many places.

(2) Takahama Fault It confines the northernmost of the metamorphic area and runs from northwest to southeast through Takahama. Although the fault can not be recognized exactly on the surface except on a few exposure, the beds, through which the fault may pass, are remarkably sheared and intruded with igneous dykes. The fault is one of the most important ones in the surveyed area, by which the Cretaceous is divided into two structural units, the southern and the northern one. Geo-tectonical differences between them are clearly seen as figured in the geological map. Between the southern and northern units, there are remarkable differences in structures of the formations from $\mathrm{B}$ to $\mathrm{H}$, although the strata younger than the Fukuregi Formation are cut and a little displaced by the fault. These facts indicate that the fault was formed before the deposition of the Fukuregi Formation, even if the fault removed again in Tertiary.

(3) Other faults Besides the faults already described many faults of NW-SE direction run parallel and converge with each other. The faults of Tororo-Koba, Komatsu-Matsuuragawachi, Komatsu-Fukuregi, Shimodaminami-Jüsanno and Imatomi-Ittyoda are good examples. They also played a role to effect the arrangements of the strata.

\section{Foldings}

(1) Ittyoda Syncline It is the most important structural element which made the major structures both of the Cretaceous and the Tertiary in Amakusa. The “Amakusa Type Structure" named by MatsushiTa (1951) is essentially expressed in the Ittyoda Synclinal structure, which is quite well perceptible at Ittyoda and its environs. The synclinal axis runs in NNE-SSW direction, and the axis plunging to the north rises to the surface near Mizukoshi and sinks again; namely the axis undulates considerably and the distribution of the strata around the axis is concave and convex. This fact may suggest that the Ittyoda Syncline was restressed from NNE to SSW after it was formed.

(2) o e Anticline An asymmetrical anticlinal axis which slightly inclines to the east stretches in Yokohama Bay. The strata at the axial part are remarkably disturbed, finely folded and steeply inclined. The anticlinal structure was not so seriously taken by the earlier workers into consideration, but the writer emphasizes here that the structural difference between the Cretaceous and the Tertiary is certainly accerelated by this anticlinal structure. The anticlinal structure is considered to have been constructed in pre-Fukuregi age.

(3) Ozaki Anticline In the Ozaki district, northern part of the mapped area, a fine anticlinal structure is perceived, the axis of which runs to NW-SE direction and plunges to the southeast. The beds are distributed semi-dome wise around the axis and incline to outerside at 20 degrees or so. All the Cretaceous strata except the A-Formation take part in this anticlinal structure and the structure is obliquely crossed by that of the Paleogene. The same as the oe Anticlinal structure, the Ozaki Anticline seems to have been constructed prior to Tertiary.

(4) Tororo Semi-dome This semi-dome is the northern branch of the Ozaki 
Anticline described above, and the strata on the eastern limb run NNW to SSE and on the western NW to SE. The formations from $\mathrm{B}$ to $\mathrm{H}$ take part in the formation of the semi-dome structure, and they come in contact discordantly with the Paleogene formations and the construction of the former is interpreted to be of pre-Fukuregi Formation.

(5) Other folding structures An anticlinal axis having NEE-SWW direction elongates in the Toishi Formation at the north of Kojima. It was, as already mentioned, formed by compression of N-S direction after the construction of the Ittyoda Syncline. Other synclinal and anticlinal structures are recognized also at some places as okōchi or the east of Takahama, but their characteristics are not always apparent. At several places semi-dome and semi-basin structures of small scale are found through the Cretaceous and the Paleogene. An imperfect anticlinal structure, at the north of Shimoda, is formed by the Paleogene strata, which was called the Shikiyama Anticline by Noтом (1930). The Shikiyama Anticline, strictly inspecting, is discordant to the Tororo Semi-dome structure although the tectonic difference is not so remarkable.

As already described, a remarkable structural difference can be recognized between the Cretaceous formations from A- to H-Formation and the overlying Paleogene formations. Based on this structural difference, a significant movement must have occurred during the time interval represented by the unconformity. Folding ratios calculated with four cross sections are higher in the formations from $\mathrm{B}$ to $\mathrm{H}$ than in the formations from Fukuregi to Sakasegawa. This result also coincides very well with the assumption mentioned above, and except HataE (1959), no one has described the existence of such a marked movement as mentioned above. He set up the clino-unconformity beneath the Akashimisaki Formation which roughly corresponds to the H-Formation and the Fukuregi Formation in this paper. But the writer believes that the movement had occurred after the deposition of the H-Formation, and a clino-unconformity was formed.

After the deposition of the H-Formation in Shimoshima, Amakusa islands and their environs were suffered from structural movement, and the movement in Shimoshima was more remarkable than in Kamishima. The general upheaval of land may have resulted in an erosional period of considerable time-range. The Tertiary sedimentary basin was formed unrelatedly with the Cretaceous one as a result of the structural movement and the subsidence mentioned before.

\section{E. Sedimentological consideration}

To make clear the characteristics of the Cretaceous and the Tertiary deposits, the writer has studied the sandstones obtained from the two systems.

\section{Classification of sandstones}

For this purpose 60 thin sections are made from medium grained sandstones collected all over the surveyed area. The modal compositions of rock forming minerals are determined with microintegrator under the polarizing microscope. Classification of sandstones is carried out in accordance to the scheme of OKADA (1968). 


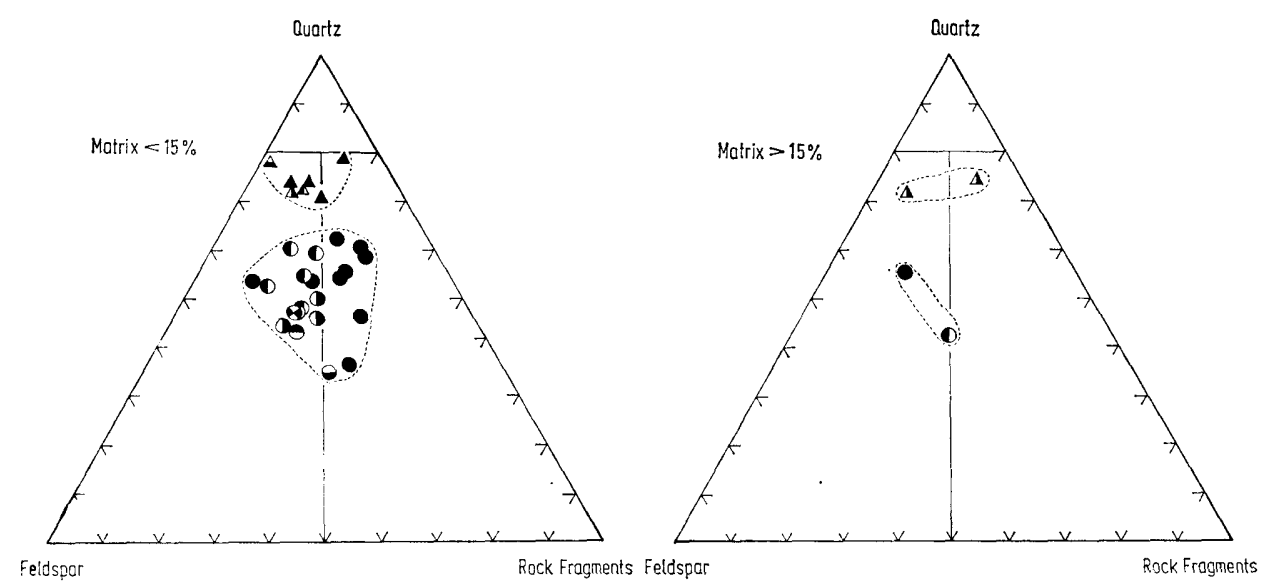

Fig. 5. Compositional diagrams of sandstones from the Sakitsu-Takahama area.

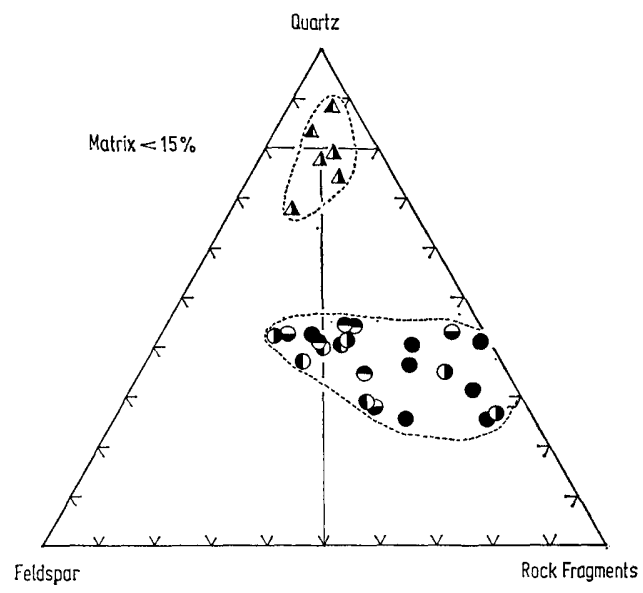

Fig. 6. Compositional diagram of sandstones from the Takahama-Tororo area.

The chief components of sandstone are, of course, feldspars, quartz and rock fragments including chert, and besides them, a minor quantity of muscovite, biotite, chlorite, calcite, epidote, glauconite, iron minerals, etc. are included. Rock fragments are originated from chert, schist, sandstone, and acidic igneous rocks. The roundness of grains varies from angular to sub-rounded and the sorting from poor to well. Because only 4 of 60 specimens belong to wacke, it may be said that most of the sandstones are arenite.

Sandstones of the Sakasegawa, Toishi, Shikiyama, and Fukuregi Formations of the Paleogene contain a large amount, more than 70 percent, of quartz. Sandstones of the B-, C-, D-, E-, F-, G- and H-Formation fall in the field of nearly 50 percent of quartz on the diagram.

\section{Heavy minerals}

The sandstone specimens for heavy mineral analysis are carefully selected among many typical sandstone samples collected from the exposures in respective 


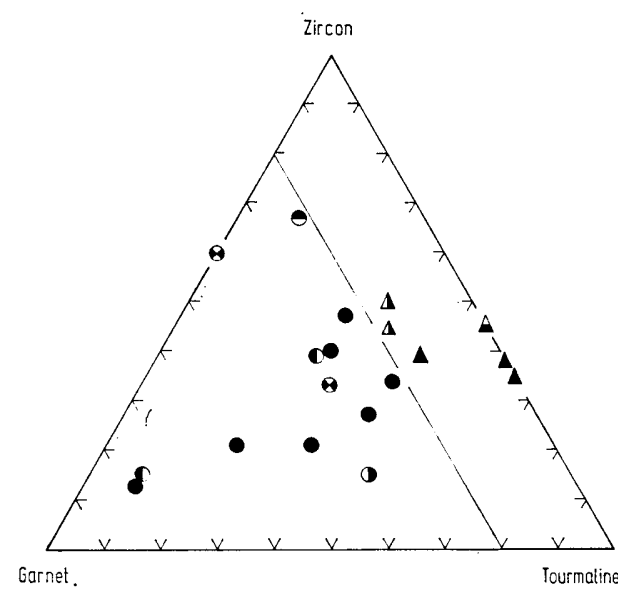

Sakitsu-Takahama Ared

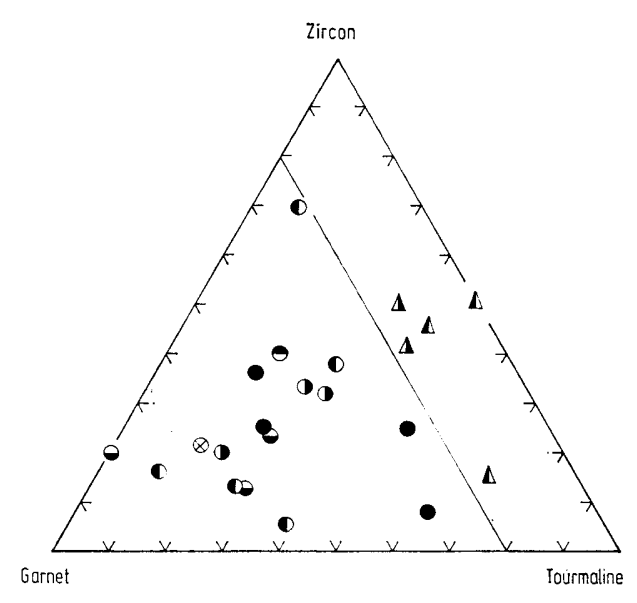

Takahama-Tororo Area

Fig. 7. ZGT diagrams of heavy minerals.

areas. The total number of the samples studied is 42 . Each specimen of about 200-300 gr. in weight is crushed with stamp mill till crushed grains pass through a sieve of 60 mesh $(0.25 \mathrm{~mm}$ opening). After quartering, the crushed specimen of $15 \mathrm{gr}$. is weighed out, and afterward cleaned up by water. Then it is gently boiled with dilute $\mathrm{HCl}$ for about 10-15 minutes on a water bath. Thus heavy minerals are separated from crushed sandstone with heavy liquid. Thoulet's solution of S.G. 2.9 is used as heavy liquid.

The heavy mineral compositions of the B-, C-, D-, E-, F-, G- and H-Formation are characterized by abundance of epidote, zircon, tourmaline, and garnet. As accessory components, glauconite, anatase and hornblende are also found. The Paleogene sandstones above the unconformity contain nearly the same heavy minerals as those of the formations from $B$ to $H$, such as zircon, tourmaline, garnet, and epidote, etc., but are characterized by reducing quantity of garnet and epidote and by an appearance of rutile even though it is really a small amount. As accessory minerals, they contain glauconite, anatase and muscovite, etc.

Thus, sandstones can be discriminated by heavy mineral compositions into two groups above and below the unconformity.

\section{Rock fragments}

Rock fragments contained in sandstones were analyzed. They consist of chert, sandstone, shale, and volcanic rocks. The percentages of chert, sandstone and shale, and igneous rocks were calculated and plotted on the triangle diagrams making them the end members.

As shown in the diagrams, the sandstones are apparently divided into two areas composed of the different components. The sandstones of the Fukuregi to Sakasegawa Formations are plotted along the chert-sandstone line. The sandstones from the B- to H-Formation occupy the area of large quantities of igneous rocks. 


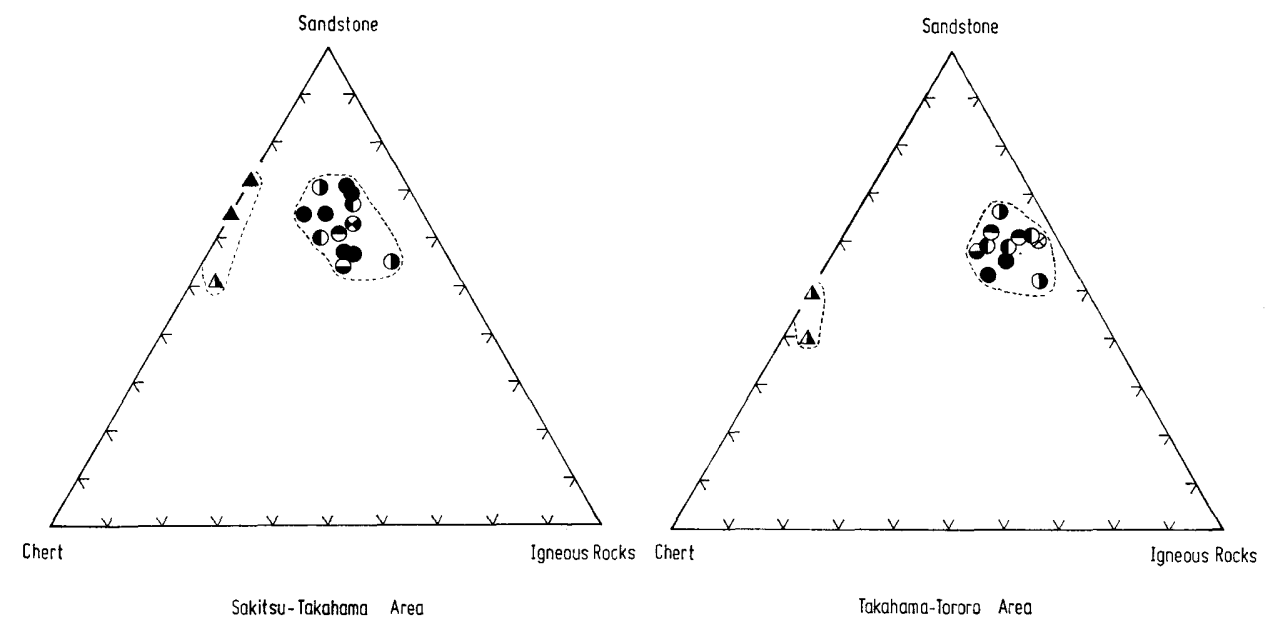

Fig. 8. Compositional diagrams of rock fragments in sandstones.

The results of petrographical laboratory work well agree with those of field works.

\section{Concluding Remarks}

The Cretaceous and the Paleogene formations distributed in the mapped area are studied. Summarizing the affairs already mentioned, the writer reaches to the conclusions as follows.

1. An unconformity is recognized beneath the Fukuregi Formation which is certainly Eocene in age on paleontological evidence. Although the available fossils in the Cretaceous sequence are not enough, the time-gap represented by the unconformity seems to be considerably large.

2. The geological structure and the characteristics of sandstones are different above and below the unconformity. This fact implies that a tectonic movement occurred during the time interval represented by this unconformity and that the geological background also changed by the movement.

\section{References Cited}

Asano, K. and Murata, S. (1958): Eocene foraminiferas from Amakusa, Kyushu (in Japanese). "Yukochu" ("Foraminifera"), (7), 23-27.

HAtaE, N. (1959): On the stratigraphical boundary between the Upper Cretaceous and Paleogene strata of Amakusa-Shimo-shima, Kumamoto Prefecture (in Japanese with English abstract). Sci. Rep., Kagoshima Univ., (8), 102-111.

(1960a): On the Nummulites zone of the island of Amakusa, Kyushu, Japan (in Japanese with English abstract). Sci. Rep., Tohoku Univ., Spec. vol. (4), 411-423.

$(1960 \mathrm{~b})$ : The geology and the geological structure of Amakusa-Shimo-shima, Kumamoto Prefecture (in Japanese with English abstract). Sci. Rep., Kagoshima Univ., (9), 61-107.

Matsushita, H. (1949): Geology of the coal fields in Northern Kyushu (in Japanese). Jour. Min. Inst: Kyushu, Spec. vol., 1-57. 
(1951): On the geological structure of the Northern Kyushu coal-fields (in Japanese). Sci. Rep. Fac. Sci., Kyushu Univ., [D], 3, (2), 49-54.

, Takai, Y., Takahashi, R., Urata, H., Iwahashi, T., Ohara, J., Tomita, S. and ОтA, K. (1959): On the geological boundary between the Cretaceous and the Paleogene in Amakusa-Shimo-shima (in Japanese). "Yukochu" ("Foraminifera"), (10), 30-41.

NAGA0, T. (1926): Stratigraphy of the Paleogene in Kyushu (I-IV) (in Japanese). Jour. Geogr., 38, (447-450), 263-269, 317-323, 369-373, 457-460.

Nотомі, S. (1930): Explanatory of the geological map of "Amakusa" (1:75000) (in Japanese with English abstract). Geol. Surv. Japan, 1-90.

OHARA, J. (1961): Heavy Mineral Associations in the Paleogene Systems of Some Coal Fields, North Kyushu, Japan. Mem. Fac. Sci., Kyushu Univ., [D], XI, (3), 381-418.

OKADA, H. (1968a): Classification and Nomenclature of Sandstones (in Japanese with English abstract). Jour. Geol. Soc. Japan, 74, (7), 371-384. $(1968 \mathrm{~b})$ : Notes on classification and nomenclature of sandstone (in Japanese with English abstract). ibid., 74, (12), 617-622.

Takai, Y. and Matsumoto, T. (1961): Cretaceous-Tertiary Unconformity in Nagashima, Southwest Kyushu. Mem. Fac. Sci., Kyushu Univ., [D], XI, (2), 257-278. and BoJo, T. (1963): On the geology of the eastern district of Shimo-shima, Amakusa coal field, Kumamoto Prefecture (in Japanese with English abstract). Bull. Geol. Surv. Japan, 14, (3), 243-256.

YABE, H. and Hanzawa, S. (1925): Nummulitic Rocks of the Island of Amakusa (Kyūshū, Japan). Sci. Rep., Tohoku Imp. Univ., VII, (3), 73-82, pls. I-V. 


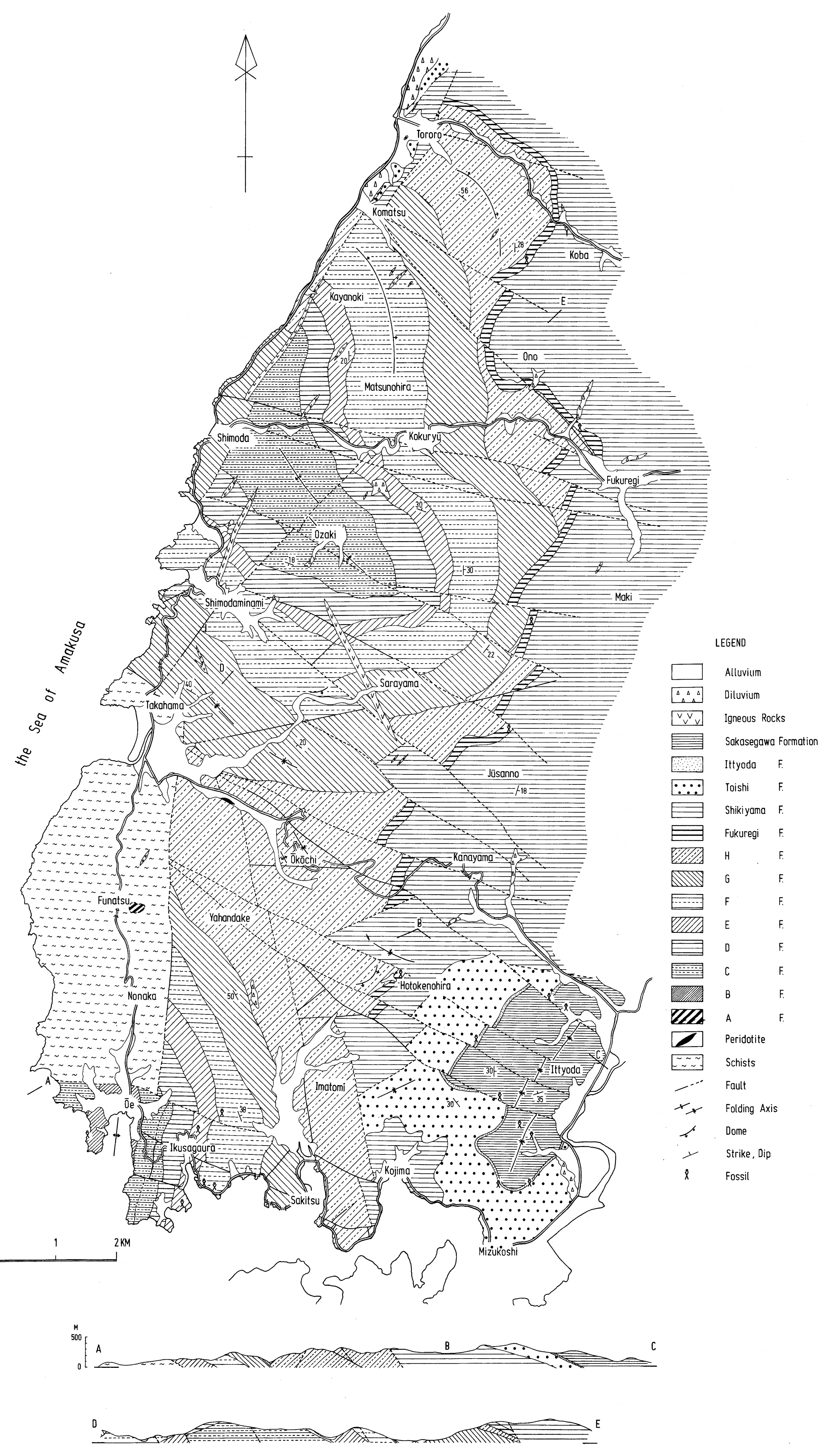

Fig. 9. Geological map and cross sections of the western part of Amakusa-Shimoshima. 
Appendix

Alphabetical list of place names

\begin{tabular}{|c|c|c|c|}
\hline Amakusa & 天 草 & Mizukoshi & 水 \\
\hline Fukuregi & 福 連 木 & Mukae & 向 \\
\hline Funatsu & 船 津 & Nakayama & 中 \\
\hline Hachikubo & 八久保 & סe & 大 \\
\hline Hirowatase & 広 渡 瀬 & ōkōchi & 大 河 \\
\hline Hondo & 本 渡 & Ozaki & 尾 \\
\hline Hotokenohira & 仏の平 & Reihoku & 苓 \\
\hline Ikusagaura & 軍ケ浦 & Sakitsu & 崎 \\
\hline Imatomi & 今 富 & Sarayama & 血 \\
\hline Ittyoda & 一 町 田 & Shiki & 志 \\
\hline Jūsanno & 十三野 & Shimoda & 下 \\
\hline Kama & 釜 & Shimodaminami & 下田 \\
\hline Kamishima & 上島 & Shimoshima & 下 \\
\hline Kanayama & 金 & Shitanoharu & 志 田 \\
\hline Kawaura & 河 浦 & Suwa & 諏 \\
\hline Kayanoki & 亘の木 & Takahama & 高 \\
\hline Kikaigaura & 鬼海ケ浦 & Takenosako & 竹 $の$ \\
\hline Koba & 木 場 & Tōge & 峠 \\
\hline Kodakahama & 小高浜 & Tomioka & 富 \\
\hline Kojima & 小島 & Tororo & 都 呂 \\
\hline Kokuryū & 石 & Tōzaki & 唐 \\
\hline Komatsu & 小 & Uchiyama & 内 \\
\hline Kumamoto & 熊本 & Ushibuka & 牛 \\
\hline Matsunohira & 松の平 & Yokohama & 横 \\
\hline Matsuuragawachi & 松浦川内 & & \\
\hline
\end{tabular}


Takashi MIKI

Cretaceous-Tertriary Unconformity in the Western Part of Amakusa-Shimoshima

Plates 34 35 
Plate 34 


\section{Explanation of Plate 34}

Photomicrographs showing the heavy minerals

z: zircon

g: garnet t: tourmaline

ep: epidote

(all figures: $\times 50$, open nicol)

Fig. 1. F-Formation

op: opaque mineral

Fig. 2. G-Formation

Fig. 3. Shikiyama Formation

Fig. 4. Toishi Formation 
Mem. Fac. Sci., Kyushu Univ., Ser. D, Vol. XXI

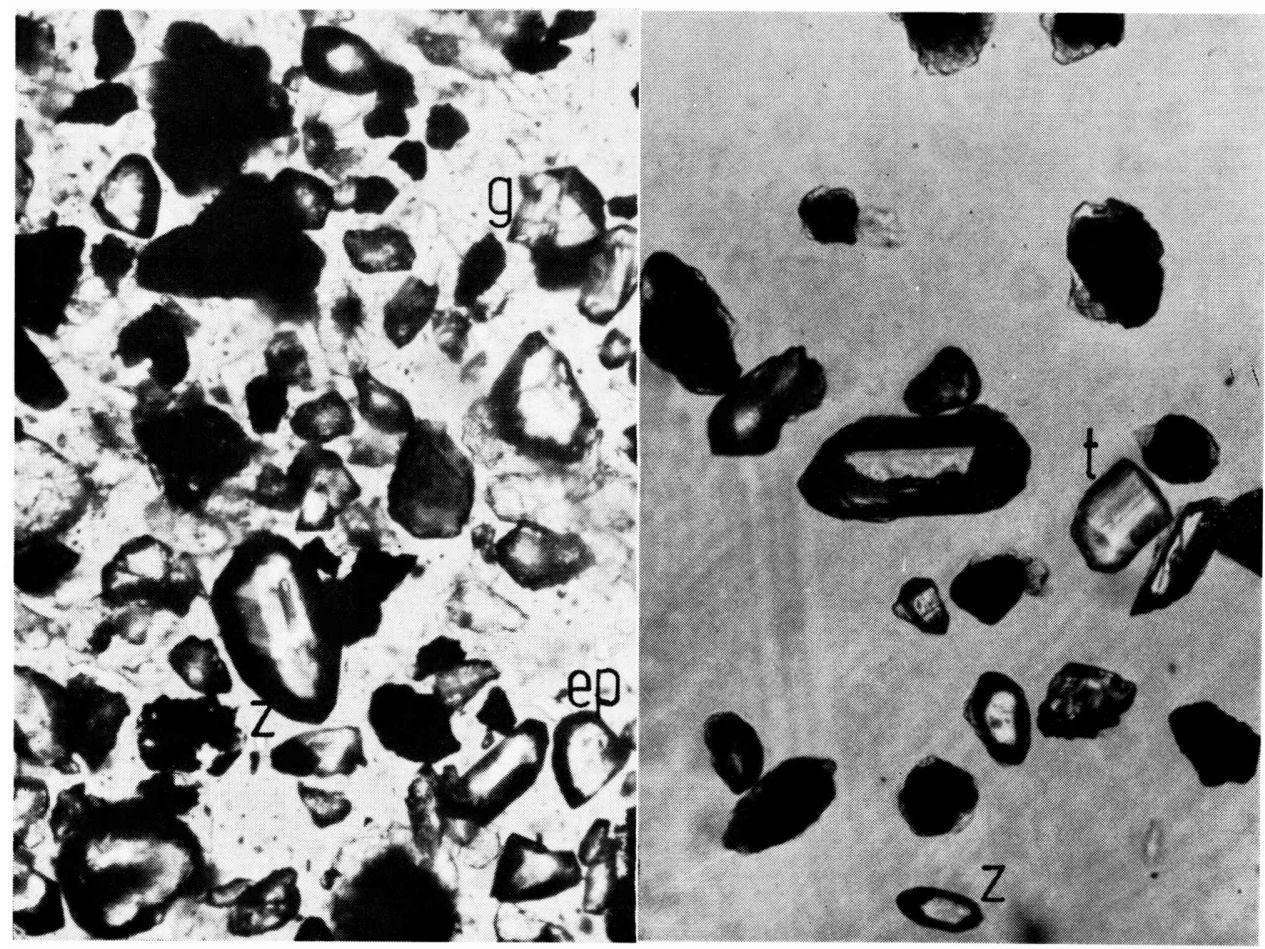

1

2

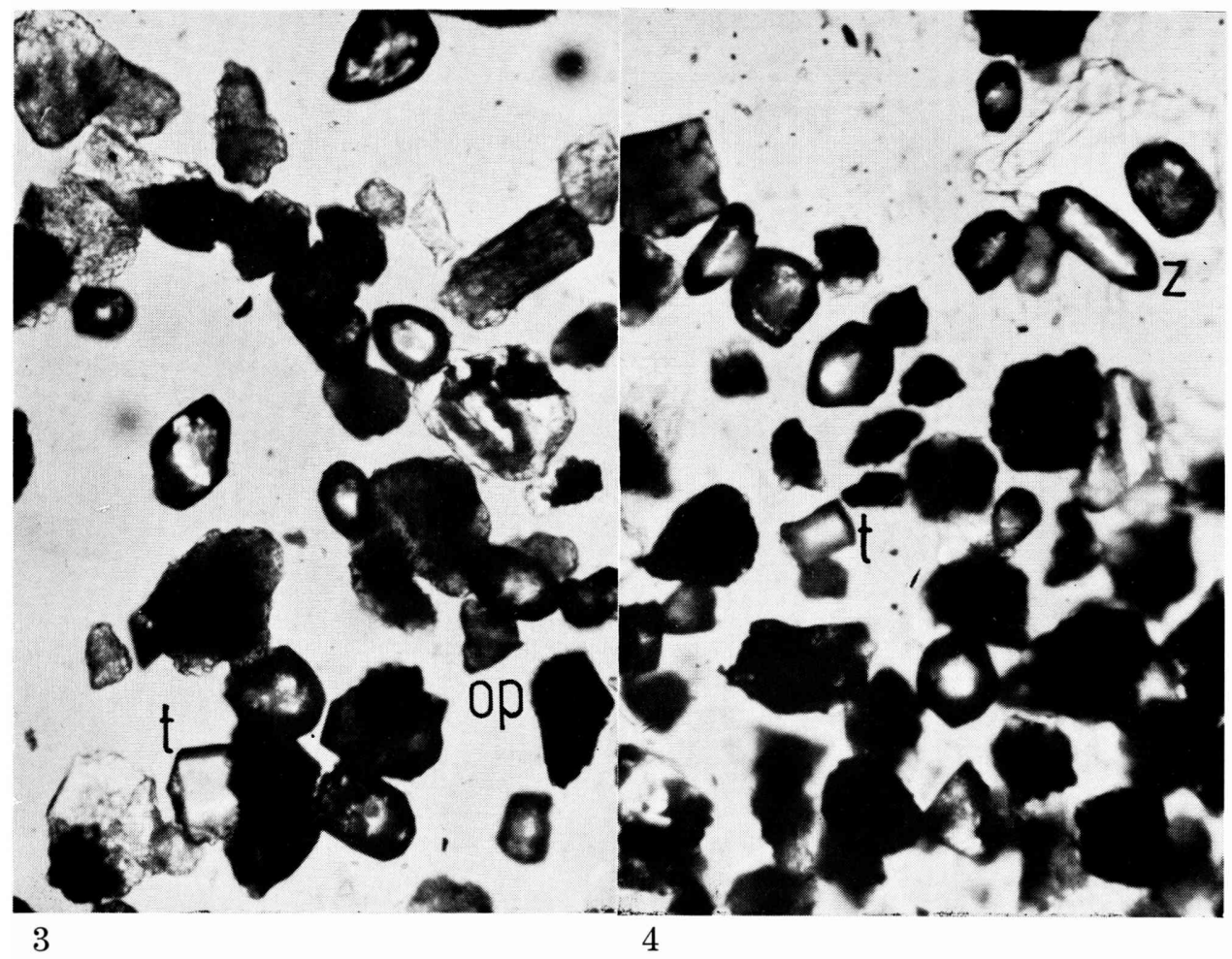

T. MIKI: Cretaceous-Tertiary Unconformity in the Western Part of Amakusa-Shimoshima 
Plate 35 


\section{Explanation of Plate 35}

Fig. 1. Unconformity between the Cretaceous and the Paleogene at Hotokenohira, Kawaura Town

unc.: unconformity

Fukuregi F.: Fukuregi Formation

H-F.: H-Formation

Fig. 2. The Shikiyama and the H-Formation

Shikiyama F.: Shikiyama Formation

H-F.: H-Formation

F.: ōe-Sakitsu Fault 


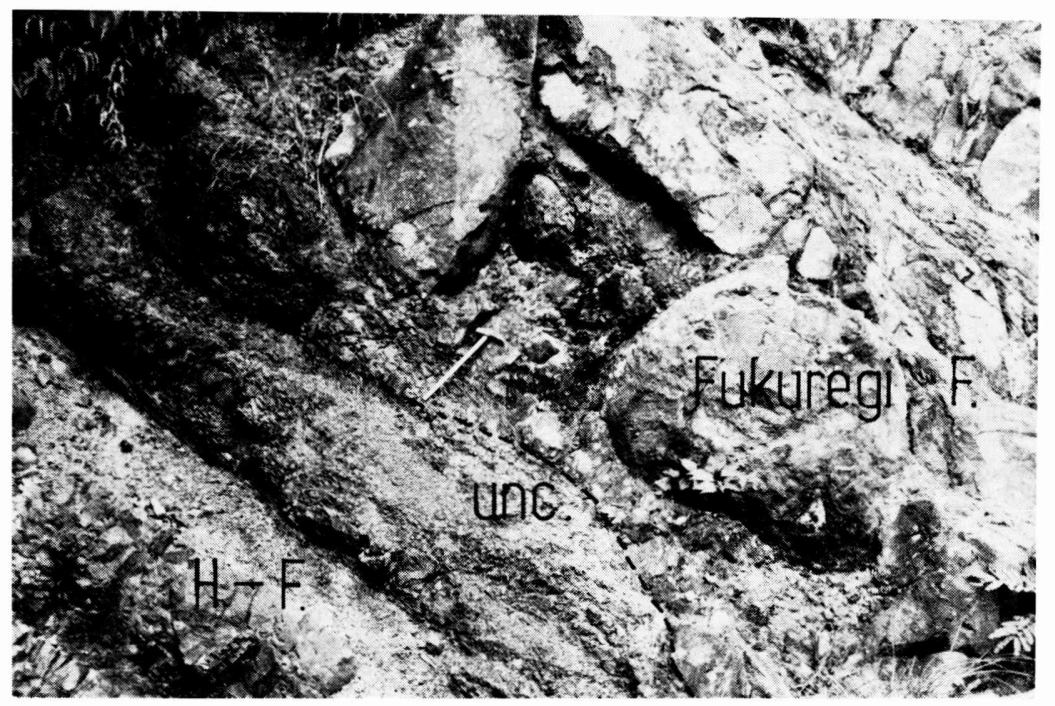

1

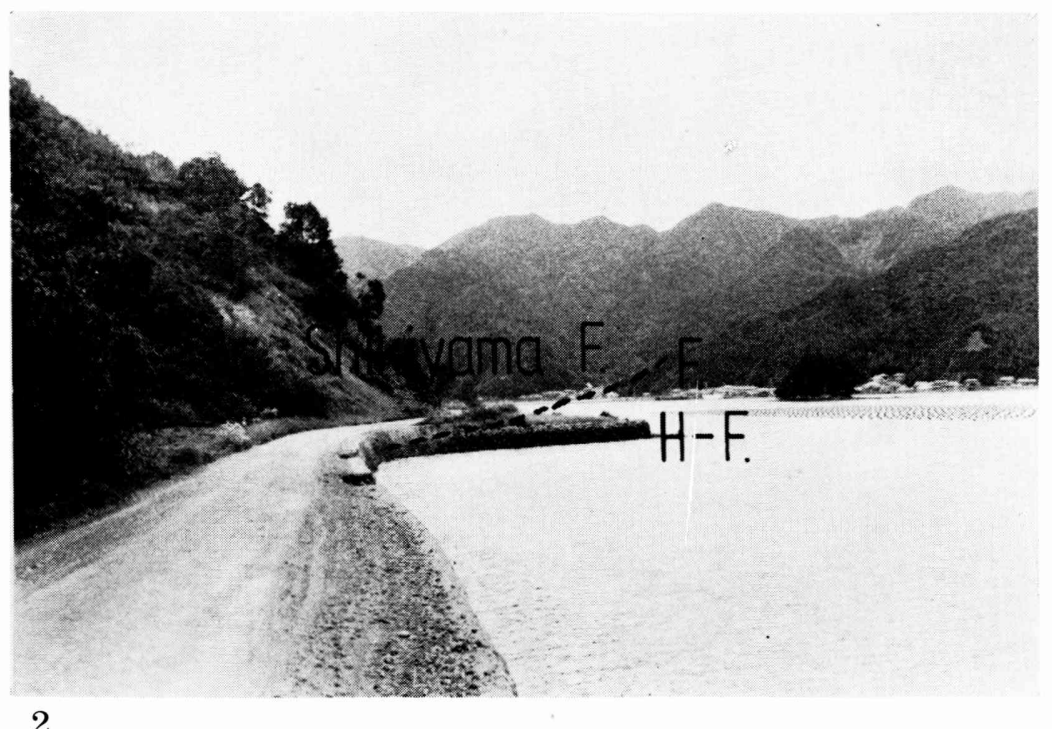

2

T. Miki: Cretaceous-Tertiary Unconformity in the Western Part of Amakusa-Shimoshima 